\title{
DENTAL BEHAVIOR MANAGEMENT OF A PATIENT WITH OSTEOGENESIS IMPERFECTA TYPE V: CASE REPORT
}

\author{
ABORDAGEM ODONTOLÓGICA DE PACIENTE COM OSTEOGÊNESE \\ IMPERFEITA TIPO V: RELATO DE CASO
}

\author{
Danilo Cassiano FERRAZ1; Ana Luiza Rodrigues RIBEIR0'; Ronan Machado de ALCÂNTARA²; Alessandra Maia de CASTRO²; \\ Fabiana Sodré de OLIVEIRA3; Danielly Cunha de Araújo FERREIRA² \\ 1 - Undergraduate student in Dentistry, School of Dentistry, Federal University of Uberlândia, Uberlândia, MG, Brazil. \\ 2 - Assistant professor, School of Dentistry, Federal University of Uberlândia, Uberlândia, MG, Brazil. \\ 3 - Associate professor, School of Dentistry, Federal University of Uberlândia, Uberlândia, MG, Brazil.
}

\begin{abstract}
Aim: the aim of this study is to report a case of a four-yearold male patient diagnosed with Osteogenesis Imperfecta (OI) type $\mathrm{V}$ and the dental care performed. Material and method: the patient has been monitored by a multidisciplinary team composed by Pediatric Dentistry, Nurse and Nutritionist at a Special Patients Center in Dentistry Hospital on the Federal University of Uberlândia since one month of life. It was reported that a child had already suffered several bone fractures and currently he has been using calcium carbonate, D vitamin and pamidronate. Results: the proposed intervention was dental preventive strategies
\end{abstract}

by parental education, caries risk assessment and controlling the dental biofilm with professional prophylaxis. But, due to the uncooperative behavior, it was used the active protective stabilization technique and mouth opener. Conclusion: it was concluded that due to the bone fragility and the risk of fractures, it is important a careful placement of the patient on the dental chair. Also, the correct use of basic auxiliary devices and advanced techniques of behavior management were relevant.

Keywords: Osteogenesis Imperfecta; Dental care; Physical restraint.

\section{INTRODUCTION}

Osteogenesis Imperfecta (OI; MIM No. 610967) is a clinically and genetically heterogeneous group of heritable disorders of connective tissue ${ }^{1}$. OI is caused by dominant autosomal mutations in the type I collagen coding genes (COL1A1 and COL1A2) ${ }^{2}$. Furthermore, is divided into type I, type II (lethal), type III (with progressively deforming phenotype) and type IV ${ }^{3}$. Since 2000 , it was considered type $\mathrm{V}$ as a new form of autosomal dominant OI caused by a dominant mutation in the $5^{\prime}$ untranslated region of IFITM5 $5^{2,4}$.

The OI provides important clinical characteristics that perform different types of this disease ${ }^{1}$. The OI shows substantial buccal and craniofacial attributes such as growth deficiency, facial class III deformity, anterior/posterior crossbite, and posterior open bite, dentinogenesis imperfecta type I - which is reported to be higher in deciduous teeth ${ }^{5-8}$. However, a significant feature is the bone fragility, leading to the tendency to fracture from minimal trauma, being known as Brittle Bone Disease ${ }^{1}$.

In the dental care of children and patients with disabilities, protective stabilization is an alternative to ensure the safety of the patient, practitioner, and staff. In addition, active immobilization involves restraint by another person, such as the parent, dentist, or dental auxiliary ${ }^{9}$. That kind of treatment brings relevance when associated with bone fragility presented in OI. The protective stabilization can be considered a risk due to bone fragility ${ }^{10}$.
Therefore, the aim of this study was to report the clinical case of a patient with OI type $\mathrm{V}$ and describe dental behavior management using basic and advanced techniques.

\section{CASE DESCRIPTION}

A four-year-old male patient has been monitored by a multidisciplinary team composed by Pediatric Dentistry, Nurse and Nutritionist at a Special Patients Center in Dentistry Hospital on Federal University of Uberlândia since one month of life. From the beginning of his follow-up, he has already attended the oral health center 7 times.

According, to the mother, gestational ultrasound and radiographic exams were performed. The exams showed fractures in fetus legs and ribs, but without the confirmation diagnosis of OI. The child was born at the $39^{\text {th }}$ week through cesarean delivery, weighing $2.515 \mathrm{~g}$ and measuring 45 centimeters.

The diagnosis of OI type $\mathrm{V}$ was 7 days after birth when a radiographic examination revealed fractures of both arms and legs, clavicle and rib. It was applied a chamois stabilization on intent to healing. In the second month of life, the child suffered a fracture in his leg during a vaccination. In the 10th month of life, another fracture had recurrence in the femur. Since then, the patient has not suffered any more fractures in this bone. Currently, the patient is under treatment and medical health care with a multidisciplinary team and takes $7,5 \mathrm{~mL}$ calcium carbonate and 3 drops of $\mathrm{D}$ vitamin per day, both medications are in 
use since his eight months of life. In addition, the patient receives intravenous pamidronate (a type of bisphosphonate chosen in the treatment of bone mineral density) since his sixth month of life. This medication is given in three doses, once a day, at the Hospital of Clinics on the Federal University of Uberlândia at intervals of four months. The patient requires being kept under observation during hospitalization.

It was observed an extraoral skeletal change, such as the triangular shape of the face, frontal bone prominence, a cephalic perimeter of $30 \mathrm{~cm}$ and absence of bluish sclera (Figure 1). He also has complete dentition, without a change in shape and number of teeth and absence of dentinogenesis imperfecta (DI). Oral hygiene was regular, with the presence of dental biofilm visible, but without dental caries.

The first dental visit occurred in the first month after birth, when preventive information was provided. The patient is regularly monitored about dental health each four months. The dental approach is strictly preventive, acting in control of biofilm, caries risk assessment, professional dental prophylaxis using a bristle brush and fluoride paste associated with dental floss.

During the dental care, it was used basic behavior management techniques to familiarize the child with the dental clinic. Despite the use of these practices, the patient often presented a non-cooperative behavior, requiring the use of active protective stabilization since his third year of life (Figure 2). It consists of the child's arms immobilization by the mother's hands. Furthermore, the mother received the general guidelines and justifications for the use of this technique. She consented to the use of them. In addition to the active protective stabilization, it was necessary a careful use of mouth opener (Figure 3 ) for the accomplishment of professional dental prophylaxis and the diagnosis of possible dental alterations.

\section{DISCUSSION}

The OI type $\mathrm{V}$ is an extremely rare disease caused by a mutation in the gene IFITM5 that presents a great phenotypic variability $^{10}$. This gene is responsible for encoding the protein BRIL, which is considered a marker of mineralizing osteoblasts ${ }^{11}$. This study presented a case report of a child earlier diagnosed with OI type $\mathrm{V}$, it is known that is a hereditary disease, and there is a report in the family of another person with the same anomaly ${ }^{3}$.

The intrauterine fracture is a finding extremely rare but can occur in certain situations such as the OI. Clinical examination and review of radiographs of long bones and the skull, as well as evaluation of dentition provide the bases for clinical diagnosis supported by imaging scans ${ }^{2}$. Choosing the type of delivery is especially important when there is a risk to the mother or the baby, and the cesarean delivery type is more suitable in OI cases ${ }^{12}$. However, despite the advances in the diagnosis of OI, the tests required for the earlier diagnosis were not performed during the prenatal period, but fortunately, the cesarean delivery was chosen avoiding bone fractures during the birth.

In relation to the pharmacological treatment, current evidences show that medicines are able to increase bone mineral density ${ }^{13}$. The use of bisphosphonate for this patient has been effective for treatment of OI, and its success may not be related to the change in the genotype of type I collagen. However, intravenous pamidronate performs an increase in bone density ${ }^{14}$.

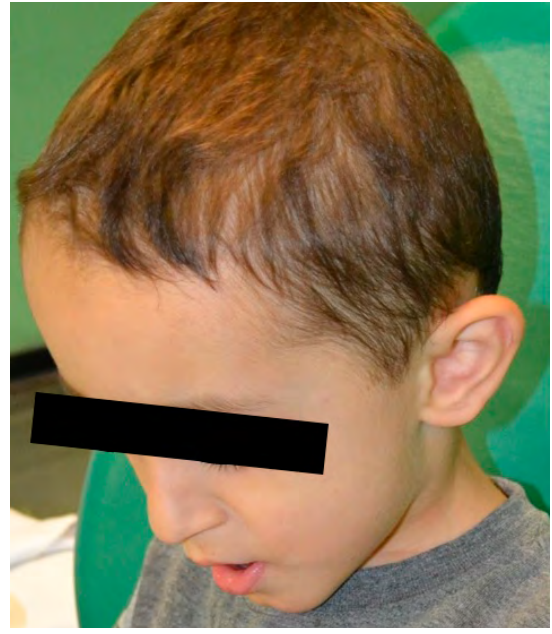

Figure 1 - Representation of extraoral skeletal change in child with Osteogenesis Imperfecta type V.

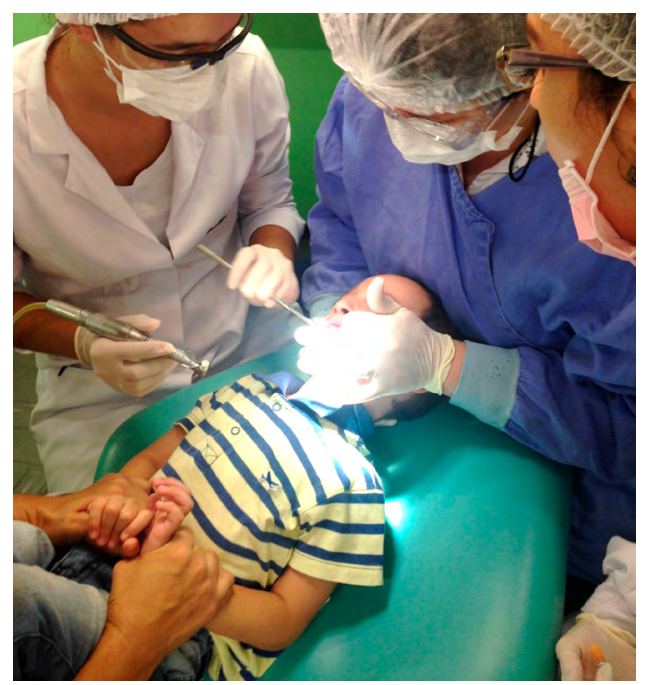

Figure 2 - Use of protective stabilization in clinical care.

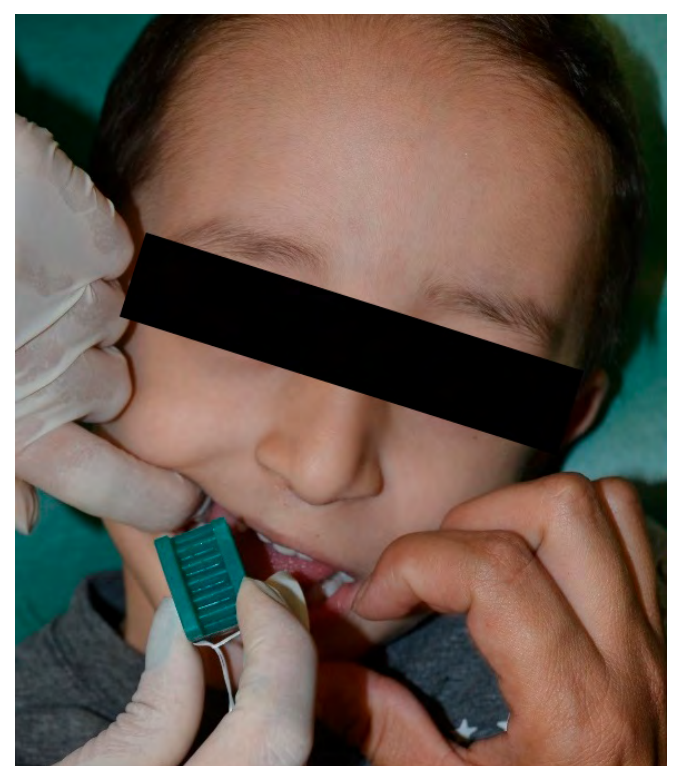

Figure 3 - Use of mouth opener as a complementary method to protective stabilization. 
In relation to the oral condition, the patient had no dental alterations or dentinogenesis imperfecta, because this is not a common feature of OI type $\mathrm{V}^{1}$. It must be emphasized that the presence of visible biofilm is not an emergency dental situation, but considering that parents had difficulties to perform oral hygiene at home, and the visible biofilm is a risk factor for early childhood caries, the decision was to perform professional prophylaxis for a more detailed dental exam.

The patient remains under preventive dental care, since, it is necessary to customize the individual needs of the treatment through protective stabilization as he remains uncooperative with the treatment.

Currently, contemporary parenting styles, expectations, and attitudes of modern parents and society have influenced the use of behavior management techniques with a prevailing emphasis on communicative techniques and pharmacological management over aversive techniques ${ }^{15}$.

For this case report, the protective stabilization was chosen, since sedation and general anesthesia were not available. Protective stabilization is a safe method appropriate for a child with little development and maturity or absence of ability to understand the importance of clinical treatments ${ }^{10}$. However, the method is followed by risks such as physical or psychological harm and violation of patient's rights. But it has already been reported in literature that active protective stabilization causes fewer injuries in comparison to passive stabilization ${ }^{16}$.

However, the method can have a high risk of bone fracture if it is done in patients who have a bone fragility exacerbated as at OI, when not performed safely and properly. It is important the presence of the parents in the care at the moment of protective stabilization, due to the trust already deposited by the child in them, making the conduct less traumatic and reducing the risks by a sudden movement for this type of patient.

Although the mouth opener device can be used to enable and maintain the mouth opening, it is not considered a protective stabilization $^{10}$. However, for the use of this device, it is necessary to perform the mouth opening of the child, often non-voluntari$1 y$, and this procedure in a patient with OI can generate serious disorders such as the risk of bone fractures. Therefore, further information must be disseminated in order to prevent the risk of bone fractures during dental care in patients with OI.

\section{CONCLUSIONS}

It was concluded that OI presents large bone fragility and fracture risks, in order to obtain an adequate and safe positioning of the patient in the dental clinic. In the same way, basic behavioral management techniques should be encouraged because they have satisfactory success rates. Furthermore, advanced behavioral management techniques such as protective stabilization can be indicated as long as they are performed with caution.

\section{REFERENCES}

01. Marini JC, Forlino A, Cabral WA, Barnes AM, San Antonio JD, Milgrom S, et al. Consortium for osteogenesis imperfecta mutations in the helical domain of type I collagen: regions rich in lethal mutations align with collagen binding sites for integrins and proteoglycans. Hum Mutat. 2007;28(3):209-21.

02. Marini JC, Forlino A, Bachinger HP, Bishop NJ, Byers PH, Paepe A, et al. Osteogenesis imperfecta. Nat Rev Dis Primers. 2017;3:17052.

03. Sillence DO, Senn A, Danks DM. Genetic heterogeneity in osteogenesis imperfecta. J Med Genet. 1979;16(2):101-16.

04. Glorieux FH, Rauch F, Plotkin H, Ward L, Travers R, Roughley P, et al. Type $\mathrm{V}$ osteogenesis imperfecta: a new form of brittle bone disease. Journal of bone and mineral research : the official journal of the American Society for Bone and Mineral Research. 2000;15(9):1650-8.

05. Dogba MJ, Rauch F, Tre G, Glorieux FH, Bedos C. Shaping and managing the course of a child's disease: parental experiences with osteogenesis imperfecta. Disabil Health J. 2014;7(3):343-9.

06. Isshiki Y. Morphological studies on osteogenesis imperfecta, especially in teeth, dental arch and facial cranium. Bull Tokyo Dent Coll. 1966;7(1):31-49.

07. Muhney K, Campbell PR. Pediatric dental management of a patient with osteogenesis imperfecta and dentinogenesis imperfecta. Spec Care Dentist. 2007;27(6):240-5.

08. O'Connell AC, Marini JC. Evaluation of oral problems in an osteogenesis imperfecta population. Oral Surg Oral Med Oral Pathol Oral Radiol Endod. 1999;87(2):189-96.

09. Association AD. Principles of Ethics and Code of Professional Conduct. American Dental Association. 2018:20.

10. American Academy of Pediatric Dentistry.. Guideline on Protective Stabilization for Pediatric Dental Patients. Pediatr Dent. 2016;38(6):199-203.

11. Moffatt P, Gaumond MH, Salois P, Sellin K, Bessette MC, Godin E, et al. Bril: a novel bone-specific modulator of mineralization. Journal of bone and mineral research: the official journal of the American Society for Bone and Mineral Research. 2008;23(9):1497-508.

12. Morgan JA, Marcus PS. Prenatal diagnosis and management of intrauterine fracture. Obstet Gynecol Surv. 2010;65(4):249-59.

13. Dwan K, Phillipi CA, Steiner RD, Basel D. Bisphosphonate therapy for osteogenesis imperfecta. Cochrane Database Syst Rev. 2014(7):CD005088.

14. Kanno J, Saito-Hakoda A, Kure S, Fujiwara I. Responsiveness to pamidronate treatment is not related to the genotype of type I collagen in patients with osteogenesis imperfecta. J Bone Miner Metab. 2018;36(3):344-51.

15. Oliver K, Manton DJ. Contemporary behavior management techniques in clinical pediatric dentistry: out with the old and in with the new? J Dent Child (Chic). 2015;82(1):22-8.

16. Spreat S, Lipinski D, Hill J, Halpin ME. Safety indices associated with the use of contingent restraint procedures. Appl Res Ment Retard. 1986;7(4):475-81.

\section{RESUMO}

Objetivo: relatar caso de paciente do sexo masculino, com quatro anos de idade, diagnosticado com Osteogênese Imperfeita (OI) tipo $\mathrm{V}$ e os cuidados odontológicos realizados. Material e método: $\mathrm{O}$ paciente foi acompanhado por equipe multidisciplinar composta por Odontopediatra, Enfermeira e Nutricionista de um Centro Especial de Pacientes do Hospital Odontológico da Universidade Federal de Uberlândia desde um mês de vida. Foi relatado que a criança já havia sofrido várias 
fraturas ósseas e atualmente está usando carbonato de cálcio, vitamina D e pamidronato. Resultado: a intervenção proposta foi de estratégias preventivas odontológicas por educação dos pais, avaliação do risco de cárie e controle do biofilme dental com profilaxia profissional. Porém, devido ao comportamento não cooperativo, utilizou-se a técnica de estabilização protetora ativa e o abridor de boca. Conclusão: concluiu-se que, devido à fragilidade óssea e ao risco de fraturas, é importante uma colocação cuidadosa do paciente na cadeira odontológica. Além disso, o uso correto de dispositivos auxiliares básicos e técnicas avançadas de gerenciamento de comportamento foram relevantes.

Palavras-chave: Osteogênese Imperfeita; Cuidado dental; Contenção física.

\section{CORRESPONDING AUTHOR}

Danielly Cunha de Araújo Ferreira

Pediatric Dentistry, School of Dentistry of Federal

University of Uberlândia

Campus Umuarama. Av. Pará 1720, Umuarama, 38405-320,

Uberlândia, MG, Brazil. Phone: +55 34 3225-8146

E-mail: danielly@ufu.br 